folk/ed. 2021; 27(2) $106 \mathrm{Ek}$

DOI: $10.22559 /$ folklor.1849

\title{
Kuzey Kıbrıs'ta Süregelen Cinsiyetlendirilmiş Ebeveynlik
}

\author{
The ongoing gendered parenting in North Cyprus
}

\begin{abstract}
Biran Mertan*
Öz

$\mathrm{Bu}$ çalışma, erken ve okulöncesi yaşta çocuğu bulunan ana babaların çocuk yetiştirme ile ilgili olarak geniş aileden aldıkları destek, babanın ücretsiz bakım emeği, annenin çalışma statüsü, sosyal bağlar, kültürel değerler, sosyoekonomik durum ve akrabalık ilişkilerinin rolünü feminist bakış açısıyla incelemektedir. Veri toplama aracı olarak Demografik Bilgiler Formu, Baba Katılım Ölçeği, Geniş Aile Desteği Ölçeği, Çocuk Günlüğü Testi ve Sürekli Kaygı Envanterinden oluşan bir soru kâğıdı kullanılmıştır. Araştırma grubu, yaşları 12 ile 60 ay arasında değişen toplam 397 çocuğun annelerinden oluşmaktadır. Annelerin 318'i ücret karşılığı bir işte çalışmakta, 79'u ise ücret karşılığı herhangi bir işte çalışmamaktadır. Çocukların ortalama yaşı 36.0 aydır. Ailelerin tamamı çekirdek aile olarak yaşamlarını sürdürmekte, \%17.9'u amalgam aile yapısı içerisinde anne ve babalarının yaşadığı bir binada ve \%3.8'i ise geniş aile yapısı içerisinde aynı evde oturmaktadırlar. Araştırmaya katılan
\end{abstract}

Geliş tarihi (Received): 27.03.2021 - Kabul tarihi (Accepted): 29.05.2021

*Prof. Dr., Uluslararası Kıbrıs Üniversitesi Fen-Edebiyat Fakültesi Psikoloji Bölümü.

ebiran.mertan@gmail.com. ORCID 0000-0002-6651-6363 
annelerin \%71.9'u geniş aileden destek aldıklarını ifade etmişlerdir. Ücret karşılığı çalışan anneler grubuna dahil çocukların yarısında (\%51.6), çocuklar en az iki yaşına gelene kadar, gün içi bakımlarının büyükanneleri tarafından yapıldığı görülmüştür. Öte yandan, babaların ücretsiz ev emeği paylaşımlarının ve çocuk bakımı sorumluluklarının sınırlı olduğu gözlemlenmiştir. Araştırma bulguları Kuzey Kıbrıs’ta sosyal çevrenin çocuk bakım yöntemi olarak aile içi bakımı desteklediğini göstermektedir. Sonuç olarak, Kuzey Kıbrıs örnekleminde, kadına yüklenen çocuk yetiştirme rolü, büyükanneler aracılıyla da devam etmektedir.

Anahtar sözcükler: cinsiyetlendirilmiş ebeveynlik, ücretsiz bakım emeği, geniş aile desteği, baba katılımı, çocuk gelişimi

\begin{abstract}
This study examines the role of extended family support for parents with children in early and pre-school age, father's unpaid care work, mother's employment status, social ties, cultural values, socioeconomic status, and kinship relations from a feminist perspective. A questionnaire composed of a Demographic Information Form, Father Involvement Scale, Extended Family Support Scale, Child's Day Test, and Trait Anxiety Inventory was used for data collection. The research sample consisted of mothers of 397 children who were aged between 12 and 60 months. A total of 318 mothers were employed in a paid job while 79 were not employed in a paid job. The average age of the children was 36.0 months. It was observed that while all the families live as nuclear families, $17.9 \%$ of them lived in a building where their mothers and fathers live as an amalgam family structure (nuclear family living very close to the extended family, for example in the same building but in separate flats), and 3.8\% lived in the same house as an extended family structure. The overall percentage of mothers who stated that they receive extended family support was $71.9 \%$. The study also showed that half of the children $(51.6 \%)$ of the employed mothers were cared for by their grandmothers during the day at least until the children reached two years of age. Furthermore, it was found that fathers' involvement was limited both in housework and childcare responsibilities. Research findings showed that the social environment in North Cyprus supports familial care as a childcare method. In conclusion, in the North Cyprus sample, the gendered child-rearing role attributed to women continues in the status of grandmothers.
\end{abstract}

Keywords: gendered parenting, unpaid care work, extended family support, father involvement, child development

\title{
Extended summary
}

The present study examines the position of women and the existing support mechanisms for women as parents in North Cyprus from a feminist perspective. A brief introduction 
on issues such as women's rights and gender equality which is at the very heart of human rights and the United Nations values will be summarized. Furthermore, the challenges and the progress achieved by Turkish Cypriot women on gender equality will be emphasized. Finally, the woman as a mother in the Turkish Cypriot family will be examined within the framework of the findings obtained by using the survey method.

The Commission on the Status of Women within the UN was established in 1946 and organized four World Women's Conferences (Mexico City, 1975; Copenhagen, 1980; Nairobi, 1985; Beijing, 1995). In 2020 for International Women's Day (8 March) several events such as the 25th anniversary of the Beijing Declaration and Platform for Action, a five-year milestone towards achieving the Sustainable Development Goals, the 20th anniversary of UN Security Council resolution 1325 on women, peace and security, and the 10th anniversary of UN Women's establishment were planned to mobilize global action to achieve gender equality and human rights of all women and girls. However, due to the unprecedented challenges from the COVID-19 pandemic that the world is experiencing, many of these events were either cancelled or became virtual events.

The social structure of the Turkish Cypriot society, like other societies in the world, is constantly and rapidly changing. Turkish Cypriot women are influenced by both oriental and occidental cultures. Cypriot women, compared to women in Turkey (December 5, 1934) gained suffrage, the right to vote long afterwards in 1960 with the declaration of the Republic of Cyprus. Subsequently, Cypriot women gained the right to vote and be elected, and also getting out of the private sphere and becoming more visible in the public sphere gained momentum, such as girls' participation in further and higher education (Dedeçağ, 1993; Mertan, 2000) and the foundation of women's organizations (Atalay \& İnan-Uzman, 1998). However, the inter-communal conflicts in the last 60 years which started soon after the Republic was announced (1963-67) and the division of the island of Cyprus (1974) affected not only the inhabitants of the island but also international political strategies, as such that the 'Cyprus Problem' and/or the 'Solution in Cyprus' are constantly on the agenda and has impeded the women's gender equality efforts and meaningful representations in the decisionmaking mechanisms (Hadjipavlou \& Mertan, 2010; 2019).

Worldwide, one out of every two adult women participates in the labor force, while this rate is calculated as three-quarters for adult men (World Bank, 2020). Approximately 380 thousand people live in North Cyprus. According to the Household Labor Force Survey (TRNC Statistical Institute, 2020) conducted in North Cyprus, the rate of participation of women in the labor force is $40.8 \%$. Women who are not employed, and women who are employed are held equally accountable for household chores and taking care of their children. Although gender equality expresses the equal and meaningful participation of women and men in all spheres of society, patriarchal understanding imposes the domestic care and childcare on women. Due to the patriarchal, sociocultural roles and responsibilities that society imposes on individuals as women or men, childcare, elderly, disabled and ill people care are predominantly attributed to women. Gender policy debates highlight the importance of access to social care services as the most effective strategy to alleviate time 
constraints on women's labor supply and to promote women's equal access to labor markets (European Commission-EC, 2015). As is the case in many parts of the world, the issue of unpaid care work is an important indicator of gender inequality for Turkish Cypriot women as well. As domestic care work is culturally perceived attributable to women, women either do not stay in the labor market or choose jobs and training fields where they can reconcile work and family life (Mertan, 2000).

Cognitive, emotional, and social development in infancy and early childhood is comprehensive and rapid. For this reason, the parent/caregiver-child relationship is of great importance during these periods (Belsky, 1984). Task sharing among family members (e.g., father, grandmother) in raising a child is important (Lamb, 2010; Mertan, 1995; Williams \& Kelly, 2005). It is common practice in small communities (e.g., North Cyprus) that extended families (e.g., grandparents) also contribute to childcare in the early years (Mertan, 2003). In every society, parents are responsible for their children's socialization and being functional individuals (Baumrind, Larzelere \& Owens, 2010). Schneider (2014) emphasizes that parenting style studies should be questioned, especially what parents do in child-rearing practices in daily life. Bronfenbrenner's (1986) Ecological Model emphasized the change in the direction of mother-baby studies and the effects of multi-directional, family, different institution/community and society interaction on both parent maturity and child development in the same process. Accordingly, as stated by Kağıtçibaş1 (2012), 'parenthood' is a product of culture on the one hand, and on the other hand, it creates culture.

Therefore, the present study examines the role of the extended family support, father's unpaid care work, mother's employment status, social ties, cultural values, socioeconomic status, and kinship relations of parents with children in early and pre-school age, on the Turkish Cypriot sample, from a feminist perspective. A questionnaire was developed for data collection. The research sample consisted of mothers of 397 children, aged between 12 and 60 months. It was observed that half of the children $(51.6 \%)$, in the employed mothers group, were cared for by their grandmothers during the day until at least they reach two years. The study also observed that fathers have limited involvement in unpaid housework and childcare responsibilities. The percentage of mothers stating that they receive extended family support was 71.9 and $21.7 \%$ live in either an amalgam or an extended family structure. Research findings show that the social environment in North Cyprus supports familial care as a childcare method. In conclusion, in the North Cyprus sample, the gendered child-rearing role attributed to women continues in the status of grandmothers.

\section{Giriș}

$\mathrm{Bu}$ çalışmada feminist bakış açısıyla Kuzey Kıbrıs’taki kadının konumu ve ebeveyn olarak destek aldığg mekanizmalar incelenecektir. Bu inceleme yapılırken öncelikle geçilen son asırda dünyada gelişen kadın hakları, toplumsal cinsiyet eşitliği gibi konular özetlenecek, daha sonra dünya ile paralel gelişme gösteren Kıbrıslı Türk kadınlarının kadın hakları konusunda geldikleri noktaya vurgu yapılacaktır. Son 
olarak Kıbrıslı Türk ailesi içerisinde anne olarak kadın, tarama yöntemi kullanılarak elde edilen veriler çerçevesinde irdelenecektir.

\section{Kadının insan hakları}

Birleşmiş Milletler (BM) Teşkilatı, kuruluşundan itibaren kadın konusu ile yakından ilgilenmiştir. İlk uluslararası yasal belge olarak 1945 yılında kabul edilen "İnsan Hakları Bildirgesi”, kadın-erkek eşitliği ilkesinin uluslararası planda kabulünün BM tarafından ilanı anlamını taşımaktadır. BM bünyesinde Kadının Statüsü Komisyonu'nun 1946 yılında kurulması ve bugüne kadar BM tarafından dört defa Dünya Kadın Konferansı (Mexico City, 1975; Copenhagen, 1980; Nairobi, 1985; Beijing, 1995) düzenlenmesi de bu ilginin göstergesidir. Kadın Haklarıyla ilgili çalışmalar hız ve yoğunluk kazanırken örneğin 2020 yılında 'sosyal koruma sistemleri, kamu hizmetlerine erişim ve toplumsal cinsiyet eşitliği ve kadınların ve kız çocuklarının güçlendirilmesi için sürdürülebilir altyapı konuları' BM Kadının Statüsü Komisyonu'nun altmış dördüncü oturumu (CSW64, 2020) konuları arasında yer almıştır (9-22 Mart 2020). Esasen 2020 yılı için yerel ve uluslararası örgütler, Beijing Dünya Kadınlar Konferansı'-Beijing Deklarasyonu ve Eylem Programı'nın 25. yıl dönümü, BM Güvenlik Konseyi 1325 sayılı kararın 20. yıl dönümü, BM Kadın Birimi'nin 10. yıl dönümü ve Sürdürülebilir Kalkınma için Küresel Amaçların 5. yıl dönümü nedeniyle birçok etkinlikler öngörmüşlerdir. Ancak, dünyayı sarsan COVID-19 salgını nedeniyle birçok etkinlik ertelenmiş veya çevrim içi etkinlik şekline dönüştürülmüştür. BM Kadının Statüsü Komisyonu'nun altmış beşinci oturumu ise (CSW65, 2021) 15-26 Mart 2021 tarihleri arasında gerçekleşmiştir. Gelişen COVID-19 salgını nedeniyle toplantıların büyük çoğunluğu çevrimiçi ortamlarda sanal formatta yapılmıştır. Söz konusu CSW65'in öncelikli teması, 'cinsiyet eşitliğinin sağlanması için, kadın ve kız çocuklarının güçlendirilmesi, kadınların kamusal yaşama tam ve etkili katılımı yanı sıra karar alma mekanizmalarına katılımı ve şiddetin ortadan kaldırılması' olmuştur.

Uluslararası sözleşmeler kapsamında temel ve ihlal edilemez bir insan hakk1 olarak tanımlanan toplumsal cinsiyet eşitliği, bireylerin, cinsiyet temelli ayrımcılığa uğramadan, eşit hak ve olanaklara sahip olarak kamusal ve özel yaşamın her alanında yer alması, görülebilmesi, kararlara katılabilmesi, 2015 Binyıl Kalkınma Hedeflerinin yerini alan Sürdürülebilir Kalkınma Amaçlarının da temel göstergeleri arasında (Hedef 5) yer almaktadır. Dünya kadınları bir taraftan kadının evlilikle ilgili hakları, eşit miras hakkı, evlilik içinde cinsel birleşmeyi reddetme hakkı, şiddete maruz kalmama hakkı, kendi malına sahip olma hakkı, gibi kadının insan hakları konuları üzerinde yoğun çalışmalar yaparken diğer taraftan da Birleşmiş Milletler öncülüğünde 1990 yılından itibaren Toplumsal Cinsiyet Eşitsizliği Endeksi ve Dünya Ekonomi Forumu tarafindan da 2007 yılından itibaren Küresel Toplumsal Cinsiyet Uçurumu Raporları yayınlanmaktadır. Her ne kadar bu raporlarda uluslararası hukuki statüsünün belirsizliğinden dolayı Kuzey Kıbrıs için herhangi 
bir veri olmasa da örneğin Türkiye için, Toplumsal Cinsiyet Eşitsizliği Endeksi, 159 ülke arasında 71. sırada, Dünya Ekonomi Forumu 2020 Küresel Toplumsal Cinsiyet Uçurumu Raporu'nda ise, Türkiye 153 ülke arasında 130. sırada yer almaktadır. Dünya Ekonomi Forumu 2020 raporuna göre dünya kadınlarının dünya erkekleri ile eşit haklara sahip olması için 100 yıl, erkeklerle eşit ücrete sahip olması ise 257 yıl geçmesi gerekmektedir.

Diğer bir endeks olan Cinsiyet Eşitliği Endeksi, Avrupa Cinsiyet Eşitliği Enstitüsü (EIGE-European Institute for Gender Equality) tarafından geliştirilen ve Avrupa Birliği'nde (AB) toplumsal cinsiyet eşitliği ilerlemesini ölçen bir araçtır. EIGE 2013 yılından itibaren yayınladığı raporlarla, iyileştirilmesi gereken alanlara daha fazla görünürlük sağlaması nedeniyle, kural koyucuların daha etkili toplumsal cinsiyet eşitliği önlemleri tasarlamalarına destek olmaktadır. Geliştirilen endeks, kadın ve erkek arasındaki uçurumu altı temel alandaki kazanımlara göre değerlendirmekte ve üye ülkelere 1 ile 100 arasında puan vermektedir. Ülkelerin puanları İşs (istihdama katılım, ayrımcılık ve işin niteliği), Para (finansal kaynaklar ve ekonomik durum), Bilgi (eğitime katılım ve ayrımcılık, yaşam boyu öğrenme), Zaman (bakım hizmetleri ve sosyal etkinlikler), Güç (politik ve ekonomik güç) ve Sağlik (statü ve erişim) alanlarına ek olarak, kesişen eşitsizlikler (intersecting inequalities) ve kadına yönelik şiddet parametreleri dikkate alınarak hesaplanmaktadır. Cinsiyet Eşitliği Endeksi (2020), güvenilir bir araç olarak, engellilik, yaş, eğitim seviyesi, doğduğu ülke ve aile tipi gibi unsurları, insanların yaşamlarında nasıl farklı yollar yaratarak toplumsal cinsiyetle kesiştiğini ve farklı kadın ve erkek gruplarının karşılaştığı farklı gerçekleri göstermektedir. Karar alma mekanizmalarında iyileştirilmiş toplumsal cinsiyet eşitliği, $\mathrm{AB}$ 'deki ilerlemenin ana itici gücüdür. Kadınların ve erkeklerin siyaset, ekonomi, medya, araştırma ve spor alanlarında karar alma süreçlerine katılımını ölçen Güç alanı, 2010'dan bu yana endeksteki tüm ilerlemelerin \%65'ini oluşturmaktadır. Ancak Güç alanı 100 üzerinden 53.5 puanla en düşük alan olmaya devam etmektedir. Avrupa Cinsiyet Eşitliği Enstitüsü’nün Cinsiyet Eşitliği Endeksi, toplumsal cinsiyet eşitliğindeki ilerlemelerin, her yıl ortalama yarım puanlık bir iyileşme ile hala salyangoz hızında ilerlediğini vurgulamaktadır. AB'nin, 100 üzerinden 67.9 puan alarak, gerçek anlamda toplumsal cinsiyet eşitliğine ulaşmaktan en az 60 yıl daha uzakta olduğu gözlemlenmektedir (EIGE, 2020). Toplumsal cinsiyet eşitliği ile ilgili tüm bu çalışmaların, Kuzey Kıbrıs'ta yaşayan kadınlar açısından nasıl geliştiği ve ilerlediği aşağıda sunulmaktadır.

\section{Kıbrıslı Türk kadınının konumu}

Kıbrıslı Türk toplumunun dünya toplumlarında olduğu gibi, toplumsal yapıs1 sürekli ve hızlı bir şekilde değişmektedir. Kıbrıslı Türk kadını hem doğu hem de batı kültürlerinden etkilenmektedir. Kıbrıslı kadınlar, Türkiye'de kadınların seçme ve seçilme hakkını 5 Aralık 1934 elde etmesinden çok sonra seçme ve seçilme 
hakkı elde etmişlerdir. Esasen, 1960 yılında Kıbrıs Cumhuriyeti'nin ilanı ile birlikte kadınların, seçme ve seçilme hakkını kazanmalarının yanı sıra, kız çocuklarının eğitimi (Dedeçağ, 1993; Mertan, 2000), kadınların örgütlenmesi (Atalay \& İnanUzman, 1998) ve kadınların özel alandan çıkıp kamusal alanda daha görünür olması hız kazanmıştır. Ancak son 60 yıl içinde yer alan toplumlararası çatışmalar (19631967) ve 1974 Kıbrıs adasının ikiye bölünmesi sadece adada yaşayanları değil uluslararası stratejileri de etkilemiş, 'Kıbrıs Sorunu' ve/veya 'Kıbrıs'ta Çözüm' çok boyutlu sorunlarla sürekli olarak gündemde kalmıştır. Süregelen ve zaman zaman uluslararası arenalarda da gündemde olan 'Kıbrıs Sorunu' ve/veya 'Kıbrıs'ta Çözüm', toplumsal cinsiyet eşitliği ve karar alma mekanizmalarında kadınların gerektiği gibi temsil edilme çabalarına ket vurmuştur (Hadjipavlou \& Mertan, 2010; 2019).

Birleşmiş Milletler düzeyindeki temel insan hakları sözleşmelerinden biri olan 'Kadına Karşı Her Türlü Ayrımcılığın Önlenmesi Sözleşmesi' (Convention on the Elimination of All Forms of Discrimination against Women-CEDAW, 1979) kadın haklarının korunmasına ilişkin uluslararası temel düzenlemelerden biri olarak kabul edilmektedir. Kuzey Kıbrıs'ın da taraf olduğu bu sözleşme ile, KKTC Meclisi 7 Şubat 1996 'da erkeklere ve kadınlara, ekonomik, sosyal, kültürel, kişisel ve siyasal haklardan yararlanmaları konusunda, eşit haklar sağlama yükümlülüğünde bulunacağını bildirmiştir. Toplumsal cinsiyet eşitliğine ilişkin bir başka uluslararası sözleşme 'Kadınlara Yönelik Şiddet ve Aile İçi Şiddetin Önlenmesi ve Bunlarla Mücadeleye İlişkin Avrupa Konseyi Sözleşmesi' kadına yönelik şiddet ve aile içi şiddetle mücadele amaciyla, Avrupa Konseyi tarafindan 11 Mayıs 2011 tarihinde İstanbul'da imzaya açılmıştır. Kısaca İstanbul Sözleşmesi olarak bilinen bu sözleşme KKTC Meclisi tarafından 5 Aralık 2011 tarihinde onaylanmasıyla birlikte, şiddetin önlenmesi, mağdurların korunması ve şiddet uygulayanların adalete teslim edilmesi, toplumun her ferdinin, özellikle de erkeklerin ve erkek çocuklarının, tutumlarını değiştirmesi yönünde sorumluluk üstleneceğini bildirmiştir. KKTC Meclisinin kadınlarla ilgili böylesi önemli uluslararası sözleşmelere taraf olması, kadınların güçlenmesi ve ilerlemesi, kadın-erkek eşitliğinin geliştirilmesi ve toplumsal cinsiyet eşitliği bakış açısının ana politika ve programlara yerleştirilmesi anlamına gelmekte ve hükümetleri bu konularda yükümlü kılmaktadır.

Dünya geneline bakıldığında her iki yetişkin kadından biri iş gücüne katılırken bu oran yetişkin erkekler için dörtte üç olarak hesaplanmaktadır (World Bank, 2020). Kuzey Kıbrıs'ta yaklaşık 380 bin kişi yaşamaktadır. Bu de facto nüfusun \%45.8'ini kadınlar oluşturmaktadır. Kuzey Kıbrıs'ta yapılan Hane Halkı İşgücü Anketine (KKTC İstatistik Kurumu, 2020) göre kadınların iş gücüne katılma oranı \% 40.8'dir. İş gücüne katılan kadınların \%90.9'u hizmet sektöründe çalışmaktadır. Kıbrıslı Türk kadınlarının \%86.0'sı ücretli, maaşlı veya yevmiyeli, \%11.7'si kendi hesabına ve işveren ve $\% 2.3$ 'ü ise ücretsiz işçi olarak çalışma yaşamında yer almaktadır. İşsizlik oranı karşılaştırıldığında kadınların (\%12.2) erkeklere kıyasla (\%9.0) daha yüksek oranda işsiz olduğunun kaydedildiği gözlenmektedir. Kadınların yoğun bir şekilde 
iş gücüne katılması ile birlikte özellikle erken çocukluk dönemde (0-36 ay) ve okulöncesi dönemde (37-72 ay) çocuğu olan çalışan anne ve babalar için gün içerisinde çocuklarının bakımı ve eğitimi için formüller yaratılmasını gündeme getirmiştir. Kuzey Kıbrıs'ta her ne kadar doğurganlık oranı 1.81 olarak hesaplanıyor olsa da, her yıl 3800 civarında çocuğun dünyaya geldiği ve 0-4 yaş arası çocuk sayısının 18500 civarında olduğu rapor edilmektedir (KKTC İstatistik Kurumu, 2019). Son yıllarda kreş ve gündüz bakım ve eğitim merkezlerinin sayısı hızlı bir şekilde artış göstermiştir. Yasal boşluklar ve bakanlıklar arası yetki karmaşasından dolayı kreş sayıları ile ilgili resmi kaynağa ulaşmak mümkün olmamıştır ancak yine KKTC İstatistik Kurumu, verileri temel alınarak Kuzey Kıbrıs'ta 3-5 yaş arası çocukların okullaşma oranının \%69.83 olduğu gözlemlenmiştir. Kuzey Kıbrıs genelinde 3-5 yaş grubu çocuk için toplamda 130 okulöncesi eğitim kurumunun olduğu (26 devlet ve 104 özel) ve yine toplamda sayıları 7799 olan bu yaş grubu çocuğun ya devlet $($ sayı $=4.088)$ ya da özel $($ sayı $=3711)$ kurumlarda eğitim almaya devam ettikleri gözlemlenmiştir (KKTC İstatistik Kurumu, 2019). Dolayısıyla, her yıl 9000 civarı erken çocukluk dönemi sıfır ile üç yaş arasındaki çocuklar ya aile içerisinde ya da özel kreş ve yuvalarda bakım görmektedir.

Ev dışında ücretli olarak çalışmayan kadınlar gibi ev dışında ücretli çalışan kadınlar da ev işleri ve çocukların bakımından sorumlu tutulmaktadırlar. Her ne kadar toplumsal cinsiyet eşitliği, kadınların ve erkeklerin toplumun her alanına eşit ve görünür biçimde katılımını ifade etse de ataerkil anlayış, ev ve çocukların bakımını kadına yüklemektedir.

Kuzey Kıbrıs gibi halen gelişmekte olan küçük bir ülkede, kadınların yaşamlarını kolaylaştıran politikalara ve hizmetlere öncelik verilmesi, toplumsal cinsiyet eşitliğinin sağlanması açısından son derece önemlidir. Ancak toplumsal cinsiyet, sosyal ve ekonomik eşitsizliklerin kesişen boyutlarından biri olmaya devam etmektedir. Kadınların siyasal (mecliste kadın siyasetçi oranı \%18) ve kamusal yaşama katılımının gözle görülür derecede düşük oranda olması ve siyasette kadın oranın \%20 eşiğine ulaşamıyor olması buna bir örnektir. Bu oran BM'nin '2030'a kadar 50-50 Gezegeni: Cinsiyet Eşitliği İçin Adım Atın' çalışmalarından çok uzaktır. Kuzey Kıbrıs'ta gelenek haline gelen sık sık değişen hükümetlerinin, kadınları ve kız çocuklarını yüksek düzeyde potansiyellerine erişmekten alıkoyan zorlukları ele almak için toplumsal hareketlilikten ve çabadan yoksun olduğu görülmektedir.

Toplumun bireylere kadın veya erkek olarak yüklediği ataerkil sosyokültürel roller ve sorumluluklar nedeniyle ağırlıklı olarak çocuk bakımı, yaşl1, engelli ve hasta bakımı kadına yüklenmektedir. Toplumsal cinsiyet politikası tartışmaları, kadınların iş gücü arzı üzerindeki zaman kısıtlamalarını hafifletmek ve kadınların iş gücü piyasalarına eşit erişimini özendirmek için en etkili strateji olarak sosyal bakım hizmetlerine erişimin önemini vurgulamaktadır (European Commission-EC, 2015). Esasen feministlerin öncelikli önerisi sosyal politikaların, programların ve projelerin 
tüm aşamalarına ve düzeylerine cinsiyet eşitliği bakış açısını katmak ve toplumsal cinsiyeti içeren ana-akımı cinsiyetlendirmektir (gender mainstreaming) (Orloff, 2009). Toplumsal cinsiyeti ana-akımlaştırmanın beş ilkesi arasında toplumsal cinsiyete duyarlı dil, (örneğin hem kadınlara hem de erkeklere yöneltilen anlatımlar, kadınları ve erkekleri eşit derecede görünür kılmalıdır), toplumsal cinsiyete özgü veri toplama ve analiz, hizmetlere eşit erişim ve hizmetlerden yararlanmak, kadınlar ve erkeklerin karar verme sürecine eşit derecede katılımı ve eşit tutum ve davranış gösterme yer almaktadır. Toplumsal cinsiyeti ana-akımlaştırma, cinsiyet eşitsizliklerini çözmeyi sağlamak için bir araçtır.

Dünyanın birçok yerinde yaşandığı gibi ücretsiz bakım emeği konusu Kıbrıslı Türk kadınları için de önemli bir toplumsal cinsiyet eşitsizliği göstergesidir. Ev içi bakım işlerinin kültürel olarak kadınlara yüklenen bir olgu olarak algılanması nedeniyle, kadınlar ya iş gücü piyasasında kalamıyor ya da iş ve aile yaşamını uzlaştırabildikleri işleri ve eğitim alanlarını seçiyorlar (Mertan, 2000). İlkkaracan (2017) Türkiye'de kadınların ev içi bakım işleri için harcadıkları ücretsiz emeğin haftada ortalama 30 saat olarak hesaplandığını, bu oranın erkekler için haftada ortalama 6 saat olduğunu vurgulamaktadır. Bu durum Ekonomik Kalkınma ve İşbirliği Örgütü (OECD) ülkelerinde, ev içi bakım işleri için harcanan ücretsiz emeği erkekler için haftada ortalama 11 saat ve kadınlar için de 24 saat olarak hesaplamaktadır (OECD, 2019a). Kadın erkek arasındaki bakım emeğinin dengesiz dağılımı ile ilgili Kuzey Kıbrıs'ta istatistiksel verinin henüz oluşturulmamasından Kıbrısı ıürk kadının durumu bilinmeyenler arasındadır. Bu eksikliğin nedenlerinden birisi OECD belgelerinde olduğu gibi birçok uluslararası belgede Kuzey Kıbrıs ile ilgili istatistiksel bilginin yer almamasıdır. Genellikle Kıbrıs'la ilgili yayınlanan uluslararası belgelerde iki farklı dipnot bulunmaktadır. Türkiye tarafından konulan dipnotta 'Kıbrıs ile ilgili bilgiler adanın güney kısmı ile ilgilidir. Ada'da hem Kıbrıslı Türkleri hem de Kıbrıslı Rum halkını temsil eden tek bir makam yoktur. Türkiye, Kuzey Kıbrıs Türk Cumhuriyeti'ni tanır. Birleşmiş Milletler bağlamında kalıcı ve hakkaniyetli bir çözüm bulunana kadar Türkiye, "Kıbrıs Sorunu" konusundaki konumunu koruyacaktır' ifadesi yer almaktadır. Öte yandan, 'OECD'nin tüm Avrupa Birliği üye devletleri ve Avrupa Komisyonu tarafindan hazırlanan dipnotta ise, 'Kıbrıs Cumhuriyeti, Türkiye dışındaki tüm Birleşmiş Milletler üyeleri tarafından tanınmaktadır. Bu belgedeki bilgiler, Kıbrıs Cumhuriyeti Hükümeti'nin etkin kontrolü altındaki alanla ilgilidir' ifadeleri yer almaktadır. Oysa, tüm dünyada olduğu gibi, bir ailenin sağlıklı bir ortamda yaşayabilmesi için çocuk bakımı, yemek pişirme, temizlik yapma, çamaşır ve bulaşık yıkama gibi işler ağırlıklı olarak Kuzey Kıbrıs'ta da kadınların ücretsiz ev emeği ile karşılanır. Ancak, bu konu ne yerel politikalarda ne de uluslararası politikalarda yerini alamamaktadır. 


\section{Çocuk bakımı}

Bebeklik ve çocukluk dönemi, çocuk bakımı, çocuk yetiştirme, ebeveyn tutumları, gibi konular diğer psikoloji konularında olduğu gibi, genellikle sanayileşmiş batı ülkelerinden gelen verilerin sonuçlarıyla yayınlanmaktadır (Arnett, 2008; Henrich, Heine \& Norenzayan, 2010; Tomlinson, Bornstein, Marlow \& Swartz, 2014). Geçmiş çalıșmalardan elde edilen bulgular, sanayileșmiş ülkelerde çocuk yetiştirme yöntemleri, annenin ücretli bir işte çalışması, çocuğun aile-dışı bakımında harcadığı haftalık süre ve aile-dışı bakım yöntemleri, çelişkili sonuçların olduğunu göstermektedir (Andersson, 2003; Balleyguier,1996; Balleyguier, Majunow, Godeau-Rébières \& Mertan, 1994; Belsky, 1988; Belsky \& Rovine, 1988; Goossens \& Van Ijzendoorn, 1990; Lamb, 1998).

$\mathrm{Bu}$ araştırmalar ayrıca, çocuğun huy gibi yapısal özellikleri (Belsky, 1984; Kagan, Snidman \& Arcus, 1998; Rubin, Burgess \& Hasting, 2002), ebeveynlik uygulamaları (Bornstein, 2012), annenin takvim yaşı (Bornstein \& Putnick, 2007), baba kat1lımı (Cabrera, \& Tamis-LeMonda, 2013; Lamb \& Tamis-LeMonda, 2004; McMunn, Martin, Kelly \& Sacker, 2017; Sicouri, et al, 2018; Rollè, et al., 2019) ve büyükanne-büyükbaba desteğinin (Tanskanen, \& Danielsbacka, 2018) bireyin gelişiminde etkili olduğu, erken çocukluk yıllarındaki deneyimlerin etkilerinin yaşam boyu sürebileceği ve aile-dışı bakım kalitesinin sosyal ve duygusal gelişim açısından önemli değişkenlerin başında gelebileceğini vurgulamaktadırlar.

Bebeklik ve erken çocukluk dönemlerinde bilişsel, duygusal ve sosyal gelişim kapsamlı vehızlıdır. Bu nedenle, sözkonusu dönemlerde ebeveyn/bakıcı-çocuk ilişkisi büyük önem kazanmaktadır (Belsky, 1984). Aile içi bireyler (örn. baba, büyükanne gibi) arasında çocuk yetiştirme konusunda görev paylaşımı (Lamb, 2010; Mertan, 1995; Williams \& Kelly, 2005) önemlidir. Geniş ailenin (örn. büyükanne/büyükbaba) de ilk yıllarda çocuk bakımına katkı koyması (Mertan, 2003) küçük toplumlarda (örn. Kuzey Kıbrıs) yaygın bir uygulamadır. Her toplumda ebeveynler, çocuklarının sosyalleşmelerinden ve işlevsel bir birey olmalarından sorumludurlar (Baumrind, Larzelere \& Owens, 2010). Schneider (2014) ebeveynlik stil çalışmalarında özellikle ebeveynlerin gündelik yaşamda çocuk yetiştirme uygulamalarında neler yaptıklarının sorgulanması gerektiğini vurgulamaktadır. Bronfenbrenner (1986) Ekolojik Modeli, anne-bebek çalışmalarının yönünün değişmesine ve aynı süreçte çok yönlü, aile, farklı kurum/topluluk ve toplum etkileşiminin hem ebeveynin gelişimine hem de çocuğun gelişimine etkilerini vurgulamıştır. Dolayısıyla, Kâğıtçıbaşı (2012)'nın ifade ettiği gibi 'ana babalık' bir taraftan kültür ürünüdür, diğer taraftan da kültür oluşturur.

$\mathrm{Bu}$ araştırma aşağıdaki konuları sorgulamaktadır:

- Kültürel değerler, sosyo-ekonomik durum, sosyal bağlar, akrabalık ilişkileri, gibi konuların, çocuk yetiştirme ile ilişkili olup olmadığı,

- Çocukların sosyal ve duygusal tepkilerinin ebeveynlerin eğitimi, eşlerin 
ücretsiz ev emeği paylaşımı, babaların katılımı, büyükanne ve büyükbaba tarafından sağlanan çocuk bakımı, annenin kaygı düzeyi gibi faktörlerle ilişkili olup olmadığını araştırmaktır.

Özet olarak, bu çalışma, erken çocukluk ve okulöncesi dönemde anne-babaların çocuk yetiştirme ile ilgili olarak, babanın ücretsiz ev emeği paylaşımı, geniş aileden alınan destek (özellikle bakıcı büyükanne bağlamında), ebeveyn (anne) eğitici tutumları ve çocukların bu eğitici tutumlara karşı gösterdikleri sosyal ve duygusal tepkinin ilişkisini incelemektedir.

\section{Yöntem}

\section{Örneklem}

Araştırma grubu, yaşları 12 ile 60 ay arasında değişen toplam 397 çocuğun annelerinden oluşmuştur. Çocukların ortalama yaşı $36.00(S S=12,96)$ ay, (ranj 11.16 - 60.09 ay) ve \% 53'lük bir oranda erkek çocuklardan oluşmaktadır. Çocukların tümü anne ve babalarıyla birlikte aynı çatı altında yaşamlarını sürdürmektedirler. Örneklemde boşanmış aile veya ayrı evde yaşayan çocuk yoktur.

Çalışmaya katılan ailelerin \%45.1'i apartman tipi konutlarda ve \%54.9'u bahçeli evlerde oturmaktadırlar. Ailelerin \%78.8'i çekirdek aile olarak yaşamlarını sürdürmekle birlikte, \% 17.9'u amalgam aile yapısı içerisinde anne ve babalarının yaşadığı bir binada ve \%3.8'i geniş aile yapısı içerisinde aynı evde oturmaktadırlar (\%21.7). Gazimağusa, Girne, Güzelyurt, Lefke, İskele ve Lefkoşa olmak üzere Kuzey Kıbrıs'ın 6 farklı bölgesinden katılımcı annelere ulaşılmıştır. Ailelerin \%28'i köy ve \%72'si kentlerde oturduklarını rapor etmişlerdir.

\section{Veri toplama aracı}

Araştırmada veri toplamak için üç bölümden oluşan bir soru kağıdı kullanılmıştır. Araştırmaya katılan annelerden bu soru kağıdını doldurmaları istenmiştir. Birinci bölüm olan Demografik Bilgiler bölümünde, annelerden yaş, eğitim düzeyi, çalışma durumu, yaşam ve yerleşim düzenlemeleri, geniş ailenin desteği, babanın ücretsiz ev emeği paylaşımı ve çocuk bakımı sorumluluğu gibi maddelere yanıt vermeleri istenmiştir. İkinci bölümde ise Türkçe adaptasyonu Mertan (2003) tarafindan yapılan "Çocuk Günlüğü Testi” (le test de la journée de bébé) (Balleyguier, 1979) kullanılmıştır. Çocuk Günlüğü Testi, annenin çocuğa gösterdiği eğitici tutumu ölçen Anne Ölçeği ve çocuğun, açlık, yakınma ve annenin yokluğu gibi stresli durumlara verdiği duygusal tepkilerin yanı sıra, çocuğun kişilere ve nesnelere yönelik davranışsal tepkilerini ölçen ve sınıflandıran Çocuk Ölçeği olmak üzere iki alt ölçekten oluşmaktadır. Annenin çocuğa karşı gösterdiği eğitici tutumları hesaplayan Anne Ölçeği, Annenin Sevecenliği (ona hikaye anlatıyor veya çocuk kitapları okuyorum), Annenin Katılığı (tekrar yemek istediğinde, onu reddederim), Annenin Eğiticiliği 
(oyuncaklarını tertiplemesini isterim), Annenin Tedirginliği (ateşi çıktığında hemen doktora götürürüm), Annenin Zayıflığı (çağırdığg zaman hemen giderim), Annenin Esnekliği (kendi başına bir odada oynaması için bırakırım), Annenin Tuvalet Eğitimini Verme Yöntemi (günde üç defadan fazla oturağa oturturum) olmak üzere toplamda 37 madde ve 7 kategoriden oluşmaktadır. Çocuğun annesine karşı gösterdiği tepkileri hesaplayan Çocuk Ölçeği ise, Anneye Karşı Sevgi (geldiğimi görünce bana doğru yürür ve benimle konuşur), Anneyi Taklit (benim bazı hareketlerimi taklit eder), Anneye Saldırganlık (beni 1sırdığı olur), Annenin Sözünü Dinleme (1srar ettiğim zaman yemeğini yer), Öz bakım (kendi başına ellerini yıkar) olmak üzere toplamda 50 madde ve 5 kategoriden oluşmaktadır. Her madde 3'lü Likert ölçeği $(0$ = Hiç Doğru Değil, 1 = Bazen ya da Biraz Doğru, $2=$ Çok ya da Sıklıkla Doğru) üzerinden değerlendirilmektedir. Son olarak, Sürekli Kayg1 Envanteri (Öner \& LeCompte, 1985) aracılığıyla annelerin genel kaygı düzeyleri ölçülmüştür. Söz konusu envanterde ise her madde 4'lü Likert ölçeği $(1$ = Hemen Hiçbir Zaman, 2 = Bazen, 3 = Çok Zaman, 4 = Hemen Her zaman) üzerinden değerlendirilmektedir.

Soru kağıdı kullanılarak oluşturulan Baba Katılımı (Babanın Ücretsiz Ev İçi Bakım Emeği ve Çocuk Bakımı Sorumluluğu alt ölçekleri) ve Geniş Aile Desteği Ölçeği ve diğer psikometrik ölçeklerin güvenirlik katsayıları tatmin edici bulunmuştur $(\alpha=.70$ - .92). Tablo 1'de veri analizlerinde kullanılan ölçeklerin kategori ve madde sayılarıyla birlikte güvenirlik katsayıları verilmektedir.

Tablo 1: Soru kağıdında kullanılan ölçeklerin kategori ve madde sayıları ve iç tutarl111kları

Ölçekler Kategoriler Madde Sayısı Cronbach

Alpha

Çocuk Günlüğü

$\begin{array}{rrrr}\text { Anne Ölçeği } & 7 & 37 & .81 \\ \text { Çocuk Ölçeği } & 5 & 50 & .92\end{array}$

Sürekli Kaygı Ölçeği

120

.80

Baba Katılımı

$\begin{array}{rccc}\text { Ücretsiz Ev İçi Bakım } & 1 & 11 & .80 \\ \text { Çocuk Sorumluluğu } & 1 & 8 & .82\end{array}$




\section{İşlem}

Kesitsel araştırma yöntemine bağlı elverişlilik örnekleme yoluyla, küçük yaşlarda çocuğu olan annelere ulaşılmıştır. Görüşmeler, anneler tarafından uygun görülen saatte ve kendi evleri, çocukların gittiği kreş/bakım merkezi, annenin çalışma yeri gibi yerlerde yapılmıştır. Görüşmeler ortalama bir saat sürmüştür. Katılımcıların gizliliğini korumak için, Mayıs 2018'de uygulamaya giren Avrupa Birliği Genel Veri Koruma Yönetmeliği yanı sıra psikologlar mesleğinin uluslararası etik ilkelerini belirleyen Amerikan Psikologlar Derneği (American Psychological Association [APA], 2017) ve Türk Psikologlar Derneği (TDP) (2004) etik standartları kullanılarak, Araştırma Öncesi Onay Formu, Araştırma Sonrası Bilgilendirme Formu ve soru kağıdı araştırmacı tarafından hazırlanmıştır. Doğu Akdeniz Üniversitesi, Psikoloji Bölümü Etik ve Araştırma Komitesi, etik ve bilimsel sakınca bulunmadığı yönünde karar almış ve tüm belgeleri onaylamıştır. Toplanan verilerin istatistiksel analizi için Sosyal Bilimler için İstatistik Paketi (SPSS 26) yazılımı kullanılmıştır.

\section{Bulgular}

$\mathrm{Bu}$ araştırmada annenlerden elde edilen veriler, erken çocukluk ve okulöncesi dönemde anne-babaların çocuk yetiştirme ile ilgili olarak, babanın ücretsiz ev emeği paylaşımı ve geniş aileden alınan destek bağlamında ebeveyn (anne) eğitici tutumları ve çocukların bu eğitici tutumlara karşı gösterdikleri sosyal ve duygusal tepkiler, betimsel ve çıkarımsal istatistiklerle aşağıda irdelenmektedir.

\section{Aileyle ile ilgili bulgular}

Araştırmaya katılan annelerin yaşının $($ Ort. $=31.84, S S=4.74)$, babaların yaşına kıyasla daha genç $($ Ort. $=35.11, S S=5.17)$ olduğu gözlemlenmiştir $(t(374)=16.29$, $p<.001)$. Aynı şekilde annelerin evlilik yaşının $($ Ort. $=24.84, S S=4.74)$ babaların evlilik yaşına $($ Ort. $=27.46, S S=3.82)$ kıyasla daha genç yaşta olduğu görülmüştür $(t$ $(331)=11.30, p<.001)$. Anne ve babaların eğitim düzeyleri kıyaslandığında annelerin $($ Ort. $=13.23, S S=2.70)$ babalara $($ Ort. $=12.845, S S=2.65)$ kiyasla daha uzun süre eğitim aldığı gözlemlenmiştir. Katılımcılar arasında okuryazar olmayan anne ve babaya rastlanmazken üniversite öncesi eğitim açısından anne ve babalar arasında farklılıklar gözlemlenmemiştir. Bir başka deyişle, anne ve babalar arasındaki eğitim açısından farklılıklar yüksek öğrenim düzeyinde görülmüştür. Annelerin \%28.3'nün lisans, \%10.6'sının yüksek lisans ve \%2.7'sinin doktora derecesine sahip oldukları görülmüştür. Babaların ise, \%31.4'nün lisans, \%5.5'nin yüksek Lisans ve \%1.5'inin doktora derecesine sahip oldukları görülmüştür.

\section{Anneyle ilgili bulgular}

Araştırmaya katılan toplam 397 annenin 253'ü (\%63.7) ücret karşıllı̆̆ tam zamanlı bir işte çalışmakta, 79’u (\%19.9) ücret karşılığı herhangi bir işte çalışmamakta, geri 
kalanlar ise (\%16.4), yarı zamanlı ücretli bir işte çalışmaktadır. Çalışan annelerin, \%64.0'ü ekonomik bağımsızlık kazanmak, \%29.0'u kariyer sahibi olmak ve \%7.0'si evde kapalı kalmamak için ücretli bir işte çalışmakta olduklarını ifade etmişlerdir.

Araştırmaya katılan annelere, evlilikleri ve çocuk sahibi olmak ile ilgili sorular sorulmuştur. Kuzey Kıbrıs'ta halen görücü usulü (\%11.3) evliliklerin olduğu gözlemlenirken araştırmaya katılan annelerin \%88.7 eşleri ile kendileri tanışıp evlenme kararı aldıklarını ve evliliklerinin de aşk evliliği (\%80.4) olduğunu ifade etmişlerdir. Çocuk sahibi olma kararını büyük çoğunlukla eşler (\%90.2) verirken küçük bir oran olsa da (\%9.8) geniş ailenin çocuk yapma konusunda genç çiftleri yönlendirdiği de gözlemlenmiştir. Araştırmaya katılan annelerin ilk kez çocuk edinme ortalama yaşı $26.64(\mathrm{SS}=2.69)$ olarak hesaplanmıştır. Annelerin \%58.2'si tek çocuk sahibi olduğunu, normal döllenme yoluyla çocuk sahibi olan annelerin çoğunlukta olduğu (\%90.0) ve doğumların dörtte üçünün sezaryen doğum (\%75.0) olduğu gözlemlenmiştir. Araştırmaya katılan annelerin ortalama doğum öncesi kullandıkları izinin 42 gün (ranj 0-270 gün) ve ortalama doğum sonrası iznin ise 60 gün (ranj 0-730 gün) olduğu gözlemlenmiştir. Çalışan annelerin \%68.5'i çocuğun hasta olması durumunda, kendisinin izin alıp çocuğa baktığını ifade etmişlerdir. kullandıkları izinin 42 gün (ranj 0-270 gün) ve ortalama doğum sonrası iznin ise 60 gün (ranj 0-730 gün) olduğu gözlemlenmiştir. Çalışan annelerin \%68.5'i çocuğun hasta olması durumunda, kendisinin izin alıp çocuğa baktığını ifade etmişlerdir.

\section{Ailenin çocuk bakım yöntemi}

Araştırma bulguları Kuzey Kıbrıs'ta sosyal çevrenin çocuk bakım yöntemi olarak aile-içi bakımı (Örn. Büyükanneler) desteklediğini göstermektedir. Şekil 1'de

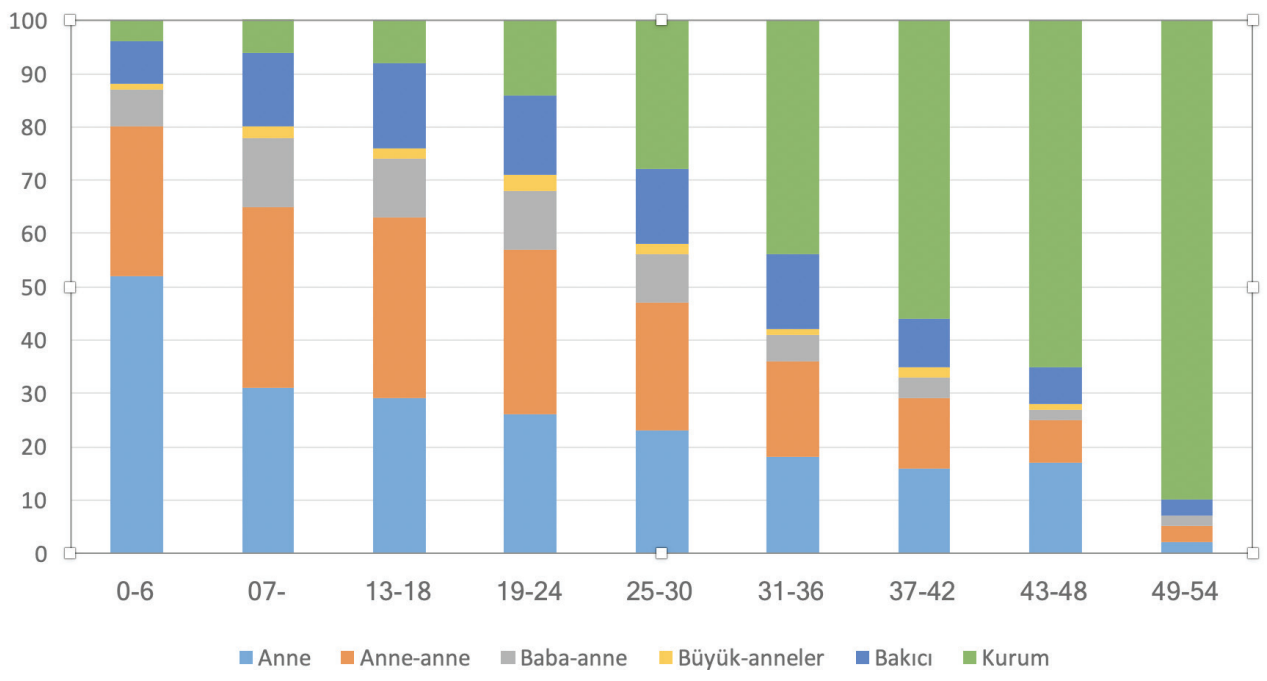

Şekil 1

Gün İçi Bakım Yöntemi (\%) 
görüldügü üzere, 0-6 ay arasındaki bebeklerin gün içerisindeki bakımı en yüksek oranda (\%51.60) anneleri tarafindan yapılmaktadır. Daha sonraki 7-12, 13-18 ve 19-24 aylık dönemlerde ise en yüksek oranda bakım sırasıyla, \%34.0, \%34.2 ve $\% 30.5$ anneanneler tarafından verilmektedir. Bu oranlar babaannelerin ve hafta içi değişimli olarak uygulanan anneanne, babaanne bakım paylaşımı ile, gün içi bakım oranları ile birleştiği zaman, 24 ay altında olan çocukların \%45.0'in üzerinde gün içi bakımlarının büyükanneleri tarafından görüldüğü gözlemlenmektedir. Kültürel olarak ilk iki yıl çocukların aile-içi bakımdan geçmelerinin çocuğun gelişimi için daha sağlıklı olacağına inanılmaktadır. Bu durum iki yaştan sonra değişerek, ebeveynlerin seçtikleri kreş, çocuk yuvası, gibi okulöncesi kurumlarda bakımeğitim almaya başladıkları görülmektedir. Beş yaş civarında çocukların büyük çoğunluğunun (\%90) gün içerisinde eğitim kurumlarında okulöncesi eğitimden yararlandığ1 gözlemlenmektedir.

\section{Geniş aile desteği}

Büyükannelerin ve büyükbabaların çocuk bakımı dışında aileye çeşitli konularda destek sağladığı gözlemlenmiştir. Araştırmaya katılan annelerin \%28.4'i geniş aileden hiç bir destek almadıklarını ifade etmişlerdir.

Destek aldığını ifade eden anneler (\%71.6), aldıkları desteği sırasıyla, aileye ait bir konutta oturduklarını (\%16.8), para yardımı aldıkların (\%16.0), yiyecek, giyecek, tatil gibi masrafların karşılandığını (\%28.9), çocuğun okul ücreti gibi masrafların karşılandığını (\%39.1), ve hafta içi öğle yemeklerini aile büyüklerinin evinde ve/ veya pişirilmiş yemeği kendi evlerine götürme (\%33.8) olarak belirtmişlerdir. Bu s1ralanan desteklerden birden fazlasını aldığını ifade eden annelerin oranı \%39.0'dur.

Annelere hafta içi kendi anne ve babasıyla ve/veya eşinin anne ve babasıyla hangi sıklıkta görüştüğü sorulmuştur. Her madde 6'l Likert ölçeği ( $1=$ Her Gün, 2 = Haftada 2-3, 3 = Haftada 1, $4=$ İki Haftada 1, 5 = Ayda 1, 6= Yılda 1'den fazla) üzerinden değerlendirilmektedir. Araştırmaya katılan annelerin ifadesine göre anneanne ve/veya babaanne ile hafta içi bir arada olma oldukça sık (\% 58.6) karşılaşılan bir olaydır. Bu durumun, annenin ücretli çalışma statüsü $($ Ort. $=2.71 S S=1.39)$ ile kıyaslandığı zaman, aile büyükleri ile olan yemek saatlerinde birlikte olma, çocuğu getirip götürme gibi günlük etkileşim üzerinde ücret karş1lığ ç̧alışmayan annelere $($ Ort. $=2.36 S S=1.02)$ göre anlamlı düzeyde farklı olduğu görülmektedir $(t(397)=$ $2.36, p<.01)$.

\section{Baba katılımı}

Araştırmaya katılan annelere, babaların ücretsiz ev içi bakım emeği ve çocuk bakım işlerinde, babaların kendilerini ne kadar sorumlu gördüklerini değerlendirmeleri istenmiştir. Her madde 4'lü Likert ölçeği $(1=$ Çok Sorumlu, 2 = Sorumlu, 3 = Biraz/ Bazen Sorumlu, 4 = Sorumlu Değil) üzerinden anneler tarafindan değerlendirilmiştir. 
Tablo 2: Babaların Ücretsiz Ev İçi Bakım Emeği ve Çocuk Bakım Sorumluluğu Ortalaması (Ort.) Standart Sapması (SS) ve Sorumluluk Yüzdesi

\begin{tabular}{|c|c|c|}
\hline & Ort. & $S S$ \\
\hline \multicolumn{3}{|l|}{ Maddeler } \\
\hline Yemek pişirme (\%13.6) & 3.30 & .79 \\
\hline Yiyecek alışverişi yapma $(\% 65.8)$ & 2.15 & .89 \\
\hline Bulaşık yıkama (\%18.8) & 3.27 & .87 \\
\hline Çamaşır yıkama/toplama (\%11.2) & 3.42 & .77 \\
\hline Ütü yapma (\%10.6) & 3.52 & .80 \\
\hline Toz alma $(\% 5.9)$ & 3.72 & .64 \\
\hline Süpürge makinesi ile temizlik (\%17.4) & 3.24 & .87 \\
\hline Yerleri silme $(\% 8.2)$ & 3.63 & .73 \\
\hline Dolap yerleştirme/tertipleme (\%13.2) & 2.13 & .80 \\
\hline Ev tamiratları ile uğraşma (\%75.1) & 2.24 & .94 \\
\hline Eve eşya alma $(\% 63.1)$ & 3.51 & .91 \\
\hline Çocuğu oyalama (\%77.4) & 1.93 & .76 \\
\hline Çocuğun altını temizleme/yıkama (\%41.7) & 2.26 & 1.05 \\
\hline Çocuğu okula götürme/getirme (\%63.9) & 1.96 & 1.05 \\
\hline Aşılarını yaptırma $(\% 64.6)$ & 2.69 & 1.07 \\
\hline Çocuğu parka götürme $(\% 60.1)$ & 2.16 & .90 \\
\hline Dans spor gibi etkinliklere götürme (\%45.7) & 2.62 & 1.00 \\
\hline Çocuğa kıyafet alma (\%36.1) & 2.84 & 1.01 \\
\hline Çocuğa oyuncak alma $(\% 58.1)$ & 2.29 & .87 \\
\hline
\end{tabular}

Not: min-max puan: $1-4$.

Annelerin ifade ettiğine göre babaların ücretsiz ev işlerinde kendilerini en çok sorumlu gördükleri, \%75.1 oranı ile ev tamiratları olmuştur. Çocuk bakımıyla ilgili olarak ise, en çok sorumluluk aldıkları \%77.4 oranla çocuğu oyalama olmuştur.

\section{Annenin eğitici ebeveyn tutumu}

Annenin eğitici ebeveyn tutumu ve çocukların annenin eğitici tutumlarına verdiği tepkiler Çocuk Günlüğü Testi ile ölçülmüştür. Aşağıdaki tablolarda Çocuk Günlüğü Testi kategorileri ve Sürekli Kaygı Envanteri aracılığılyla, annenin genel kayg1 düzeyi, annenin çocuğa karşı eğitici tutumu ve çocuğun anneye karşı sosyal ve duygusal tepkileri t testi ile hesaplanmıştır. 
Tablo 3: Anne Ölçeğindeki Kategorilerin Anne Kaygı Düzeyine Göre Kıyaslanması

\begin{tabular}{llllll}
\cline { 2 - 6 } & \multicolumn{2}{c}{$\begin{array}{c}\text { Düşük Kayg1 } \\
\mathrm{n}=219\end{array}$} & \multicolumn{3}{c}{ Yüksek Kayg1 } \\
& \multicolumn{1}{c}{ Ort. } & SS & Ort. & SS & t-test \\
\hline Annenin Sevecenliği & 16.71 & .35 & 16.37 & .37 & .91 \\
Annenin Katılığı & .62 & .34 & .75 & .37 & $3.46^{* * *}$ \\
Annenin Eğiticiliği & 11.92 & .48 & 13.25 & .45 & $3.37^{* * *}$ \\
Annenin Tedirginliği & 10.80 & .50 & 12.57 & .50 & $3.45^{* * *}$ \\
Annenin Zayıfllğı & 15.02 & .39 & 15.89 & .37 & $2.24^{* *}$ \\
Annenin Esnekliği & 13.04 & .48 & 14.35 & .49 & $2.64 * * *$ \\
A. Tuvalet Ĕğitimini Verişi & .72 & .51 & .75 & .53 & -.68 \\
\hline
\end{tabular}

Yüksek kayg1 düzeyi anneler grubundaki anneler düşük kayg1 düzeyi anneler grubundakilere kıyasla, çocuklarına daha katı $(t(396)=3.46, p<.001)$ daha eğitici $(t(396)=3.37, p<.001)$, daha zayif $(t(396)=-2.24, p<.001)$ ve daha esnek $(t(396)$ $=2.64, p<.001)$ tutum göstermişlerdir. Annenin kaygı düzeyi, annenin sevecenliği kategorisi için anlamlı düzeyde farklılık ortaya koymamıştır.

Tablo 4: Çocuk Ölçeğindeki Kategorilerin Annenin Kayg1 Düzeyine Göre K1yaslanmas1

\begin{tabular}{llllll} 
& \multicolumn{2}{c}{ Düşük Kayg1 } & \multicolumn{3}{c}{ Yüksek Kayg1 } \\
$\mathrm{n}=219$ & & \multicolumn{3}{c}{$\mathrm{n}=178$} \\
\cline { 2 - 6 } & Ort. & SS & Ort. & SS & $t$-test \\
\hline Anneye Sevgi & 16.25 & .33 & 16.65 & .38 & 1.12 \\
Anneyi Taklit & 14.71 & .46 & 14.30 & .51 & .82 \\
Anneye Saldırganlık & .45 & .37 & .59 & .41 & $3.53^{* * *}$ \\
Annenin Sözünü Dinleme & .61 & .39 & .76 & .45 & $3.53^{* * *}$ \\
Özbakım & 14.19 & .46 & 14.53 & .49 & -.69 \\
**** $p<.001$ & & & & &
\end{tabular}

İstatistiksel düzeyde anlamlı farklılık gösteren Anneye Saldırganlık ve Annenin Sözünü Dinleme kategorileri olmuştur. Yüksek kaygı düzeyi anneler grubundaki çocuklar düşük kaygı düzeyi anneler grubundakilere kıyasla, annelerinin sözünü $(t(396)=3.53, p<.001)$ daha çok dinleme ve daha saldırgan davranışlar göstermişlerdir $(t(396)=3.53, p<.001)$. 
Tablo 5: Değişkenler Arasındaki Pearson Korelasyon Katsayıları $(n=397)$

\begin{tabular}{|c|c|c|c|c|c|c|c|c|c|}
\hline & 1 & 2 & 3 & 4 & 5 & 6 & 7 & 8 & 9 \\
\hline 1. Tek çocuk & 1 & & & & & & & & \\
\hline 2. Anneanne Görüşme Sıklığ & -.052 & 1 & & & & & & & \\
\hline 3. Babaanne Görüşme Sıklığ & -.018 & $.103 *$ & 1 & & & & & & \\
\hline 4. Maddi Destek & .035 & $.219 * *$ & $.168^{* *}$ & 1 & & & & & \\
\hline 5. Bakıcı Büyükanne & .090 & $.359 * *$ & -.060 & $.175^{* *}$ & 1 & & & & \\
\hline 6. Baba Katılımı & $.099 *$ & -.017 & .014 & .031 & .070 & 1 & & & \\
\hline 7. Görev Paylaşımı & .072 & -.050 & $.146^{* *}$ & -.013 & $.102 *$ & $.549 * *$ & 1 & & \\
\hline 8. Anne Eğitici Tutumları & -.088 & -.098 & .036 & .007 & -.027 & -.007 & .082 & 1 & \\
\hline 9. Sosyo-duygusal Tepkiler & .035 & $.163 * *$ & .093 & .005 & .073 & .040 & $.137 * *$ & $.559 * *$ & 1 \\
\hline
\end{tabular}

* $p<.05 .{ }^{*} * p<.01$

Araştırmada kullanılan değişkenler arası ilişki Pearson korelasyon testi ile hesaplanmıştır. Tablo 5'te görüleceği üzere, anneanne ile görüşme sıklığı ile babaanne görüşme sıklığı $(r(397)=.103, p<.05)$ ve bakıcı büyükanne $(r(397)=.357, p<.01)$ arasında da anlamlı ve pozitif yönlü bir ilişki vardır. Büyükanne ve büyükbaba tarafından sağlanan maddi destek, hem anneanne ile görüşme sıklığ $(r(397)=.219$, $p<.01)$ hem de babaanne ile görüşme sıklığı $(r(397)=.168, p<.01)$ yanı sıra bakıc1 büyükanne $(r(397)=.175, p<.01)$ dolayısıyla her üç değişkenle, arasında anlamlı ve pozitif yönlü bir ilişki olduğunu göstermiştir. Aynı şekilde anneanne ile görüşme sıklığı ve çocuğun sosyal ve duygusal tepkileri $(r(397)=.103, p<.05)$ arasında da anlamlı ve pozitif yönlü bir ilişki olduğu gözlemlenmiştir. Tek çocuk sahibi olmak ve babanın çocuk bakım sorumluluğu $(r(397)=.099, p<.05)$ arasında anlamlı ve pozitif yönlü bir ilişki vardır. Babaların ücretsiz ev emeği değişkeniyle, babaanne ile görüşme sıklığı $(r(397)=.146, p<.01)$, bakıcı büyükanne $(r(397)=.102, p<.05)$ ve babanın çocuk bakımı sorumluluğu değişkenleri $(r(397)=.549, p<.01)$ arasında anlamlı ve pozitif yönlü bir ilişki bulunmuştur. Babanın ev içi ücretsiz emeği ve çocuğun sosyal ve duygusal tepkileri $(r(397)=.137, p<.01)$ arasında da anlamlı ve pozitif yönlü bir ilişki olduğu gözlemlenmiştir. Son olarak annenin eğitici tutumları ve çocuğun sosyal ve duygusal tepkileri $(r(397)=.559, p<.01)$ arasında anlamlı ve pozitif yönlü bir ilişki olduğu görülmüştür 
Tablo 6: Çocuğun Sosyal ve Duygusal Tepkilerinin Anne ve Baba Eğitim Düzeyi, Anne Kaygı Düzeyi, Büyükanne Bakımı ve Anne Eğitici Tutumu Tarafından Yordanmasına İlişkin Hiyerarşik Çoklu Regresyon Analizi

\begin{tabular}{llc}
\hline & \multicolumn{2}{l}{ Çocuğun Anneye Karşı Sosyal ve Duygusal Tepkisi } \\
\cline { 2 - 3 } Yordayıcı Değişkenler & $R^{2}$ & $\beta$ \\
\hline Blok 1 & $0.04^{* * *}$ & \\
Kontrol Değişkenleri & & \\
Blok 2 & & $0.27^{* * *}$ \\
Anne Eğitici Tutumu & & $0.55^{* * *}$ \\
Büyükanne Bakımı & & $0.09^{* * *}$ \\
$R^{2}$ & $0.31^{* * *}$ & \\
$N$ & 397 & \\
\hline
\end{tabular}

${ }^{a}$ Kontrol değişkenleri Annenin eğitim düzeyi, Babanın eğitim düzeyi ve Annenin kaygı düzeylerini içermektedir. $\beta$ Standardize beta katsayıs $* * * p<.001$.

Çocuğun sosyal ve duygusal tepkilerinin hangi değişkenlerle ilişkili olduğunun saptanması için iki adımlı hiyerarşik regresyon analizi yapılmıştır. Tüm değişkenler analize girdikten sonra modelin anlamlı olduğu, çocuğun sosyal ve duygusal tepkilerini \%31 oranında açılayabildiği görülmektedir $(F(5,397)=28.78, p<$ $.001, R 2=.31$ ). Tablo 6 'da görüleceği gibi annenin eğitim düzeyi, babanın eğitim düzeyi ve annenin kaygı düzeyi kontrol edildikten sonra ikinci adımda eklenen anne eğitici tutumu ve büyükanne bakımı yordayıcı değişkenleri, modeli anlamlı şekilde değiştirerek çocuğun sosyal ve duygusal tepkilerini \%27 oranında açıklamaya yardımcı olmuştur. İkinci adımda eklenen yordayıcı değişkenlerin her biri anlamlı şekilde modele katk1 koyarken annenin eğitici tutumunun $(\beta=.55)$ büyükanne bakımından $(\beta=.09)$ daha güçlü yordayıcı olduğu görülmektedir.

\section{Tartışma}

Son yarım asırda, Kıbrıs adasında süregelen çatışma ve savaşlar kültürel olarak her ne kadar toplumsal cinsiyet eşitliği çabalarına ket vurmuşa da Kıbrıslı Türk kadını 1902 yılında çıktığı eğitim serüvenini sürdürmüştür (Dedeçay, 1993; Mertan, 2000). Günümüz kadını eğitimin her düzeyinde erkeklerle yarışır durumdadır, hatta lisans üstü düzeyde diplomaya sahip olma konusunda kadınlar, erklerden \%1.8 daha fazladır (KKTC İstatistik Kurumu, 2020). Bu bulgu çalışmaya katılan annelerde (\%6.7) babalara kıyasla (\%3.5) daha yüksek oranda yüksek lisans ve doktora derecesine sahip olma olarak gözlemlenmiştir. Annelerin her düzeyde eğitim almış 
olmaları onların yoğun bir şekilde ücretli iş gücüne (\%80) katılmalarını sağlamakta olduğunu göstermiştir. Araştırmaya katılan erken ve okulöncesi dönemde çocukları olan annelerin özellikle tam zamanlı olarak ücretli bir işte çalışmaları (\%63.7) beraberinde çocuk bakım gereksinimini de getirmiştir.

Kadınların daha yüksek derecede eğitim almaları evlenme ve çocuk edinme yaşlarını da süreç içerisinde yükseltmiştir. Araştırmaya katılan annelerin ortama olarak 24.8 yaşında evlendikleri ve ortalama olarak 26.6 yaşında da ilk kez çocuk sahibi oldukları bulunmuştur. AB ülkelerinde ilk kez çocuk edinme yaşı ise 29.4 olarak verilmektedir (Eurostat, 2019). Bu durum önceki kuşaklara kıyasla çocuk yaşta denecek evliliklerin kalmadığını ve daha bilinçli ve olgun yaşta evlenme ve çocuk edinme karar1 verildiğini göstermektedir.

$\mathrm{Bu}$ araştırmada ortaya çıkan önemli bir bulgu, sezaryen doğum oranlarının Dünya Sağlık Örgütü'nün (WHO) 1985'ten bu yana ideal sezaryen oranı olarak öngördüğü \%10-15'in çok üzerinde olmasıdır (WHO, 2015). WHO sezaryen doğumların tıbbi nedenler olması durumunda hayat kurtarıcı ve gerekli bir işlem olabileceğini ancak anne ve yenidoğan ölüm hızlarındaki azalmayla ilişkili olmadığını vurgulamaktadır. Sezaryen oranları OECD (2019b) ülkeleri arasında kıyaslandığı zaman, İskandinav ülkeleri (İzlanda, Finlandiya, İsveç ve Norveç), İsrail ve Hollanda'da tüm canlı doğumların \%15 ila \%17'si arasında değişen oranlarla en düşük seviyede olduğu görülmektedir. Buna karşılık tüm doğumların \%45 ila \%53'ü arasında değişen oranlarla Kore, Şili, Meksika ve Türkiye'de de en yüksek orandadır. OECD ülkeleri genelinde canlı doğumların \% 28'i sezaryen doğum olarak yapılmaktadır. Türkiye $\% 53$ oranı ile 34 OECD ülkesi arasında en yüksek sezaryen doğum oranına sahiptir. $\mathrm{Bu}$ araştırmada sezaryen doğum oran $1 \% 75$ 'dir. Bu oran WHO'nun önerdiği oranın ve OECD istatistiklerinin oldukça üzerindedir. Araştırmaya katılan anneler, sezaryen doğum nedeni olarak, ya kendi tercihleri ve/veya doktorun yönlendirmesi yanıtını vermişlerdir. Oysa, WHO tarafından yapılan çalışmalar sezaryen doğumun anne ve yenidoğan üzerindeki psikolojik sağlık açısından etkilerinin olabileceğini ancak bu konuda bilimsel çalışmaların artırılmasına da gereksinim olduğunu vurgulamaktadır (WHO, 2015). Kuzey Kıbrıs yüksek sezaryen doğum oranı ile bu tür araştırmalara katkı koyabilecek bir konumdadır. Boylamsal yöntem kullanılarak ileriki araştırmalarda sezaryen doğumla dünyaya gelen çocukların gelişimi ve anne-bebek ilişkileri araştırılabilir.

Kuzey Kıbrıs'ta var olan Sosyal Güvenlik Yasası (2015) altında İş Yasası'nın 56. Maddesi'ne göre çalışan kadınlara, 'Kadın işçilerin doğumdan önce altı ve doğumdan sonra altı hafta olmak üzere toplam on iki haftalık' bir izin kullanma hakkına sahip olduğunu vurgulamaktadır. Yine bu yasaya göre 'Doğum yapan kadın işçilere, doğum tarihinden itibaren, dokuz ay süreyle bir saat sabah ve bir saat öğleden sonra olmak üzere günde iki saat emzirme izni' hakkı verilmektedir. Çocuk bakımıyla ilgili bu kısıtlayıcı yasal düzenlemeler yanı sıra 0-3 yaş için yeterli sayıda kreşlerin olmaması, ücret karşılığı çalışan anneler için iş-aile yaşamını uzlaştırılabilmesi 
ancak geniş aile desteğiyle mümkün olabilmektedir. Bu konunun sosyal politikalar çerçevesinde toplumsal cinsiyete duyarlı 'ebeveyn izni' yaklaşımıyla özellikle çalışan kadınların hakları ve aile ve iş yaşamını uzlaştırma noktasında yeniden ele alınması gerekmektir. Bu konularda başarılı olan İzlanda, Norveç, İsveç ve Finlandiya gibi ülkeler ebeveyn izin süresi (Örn. 45-163 hafta), maaş ve iş güvencesi (Örn. çocuk 9 yaşına gelinceye kadar) model olarak alınabilir (Ray, Gornick ve Schmitt, 2010). Ebeveyn izninin kadın/annenin ve erkek/babanın sorumlulukları bağlamında toplumsal cinsiyet eşitliğine duyarlı dönüştürücü politikalar içerisinde ele alınması, Kuzey Kıbrıs'taki ailelere çocuk yetiştirme konusunda destekleyici olabilecektir.

Araştırmaya katılan annelerin eğitim firsatlarından oldukça yararlanabildiğini ve ücret karşılığı çalışarak kamusal alanlarda etkin yer aldığı gözlemlenmiştir. Ancak annelerin iş gücü piyasasında olabilmeleri, ev içi ücretsiz emek yükü ve ücret karşılığı çalışma yükü dolayısıyla iş-aile yaşamı zaman dağılımı arasındaki denge ile bağlantılıdır (İlkkaracan, 2013; 2017). Araştırma bulguları ücret karşılığ çalışan annelerin gün içi çocuk bakımı için en büyük desteği geniş aileden aldığını göstermiştir. Özellikle çocuklar yaşamlarının ilk iki yılını büyükanne (\%45) bakım ve eğitimi alarak büyümektedirler. Esasen, araştırmaya katılan aileler geniş aileden gün içi bakım desteği yanı sıra farklı konularda maddi destek aldıklarını bildirmişlerdir (\%71.6). Bu destekler arasında geniş aileye ait bir konutta örneğin amalgam aile yapıs1 (\%21.7) içerisinde yaşamlarını sürdürmekte dahildir. Aileler her ne kadar kendilerine ait apartman dairesinde çekirdek aile olarak yaşıyor olsalar da (Şekil 2), diğer dairelerde yine çekirdek aile olarak yaşayan örneğin büyükanne ve büyükbabalar, teyze/dayı, hala/amca gibi yakın akrabalarla aynı binayı paylaşmaktadırlar (Mertan, 2003; Mertan \& Boulanger-Balleyguier, 2008). Bu amalgam aile ortam1, aile bireylerini daha s1k bir araya getirme, birlikte sosyal etkinlikler yapma ve en önemlisi gün içi çocuk bakımını kolaylaştırmaktadır. Geniş aile ile bir arada olma, özellikle büyükanne büyükbaba evinde hafta içi birlikte yemek yeme, araştırmaya katılan annelerin en az üçte birinin yaşadığı bir durum olarak ortaya çıkmaktadır.

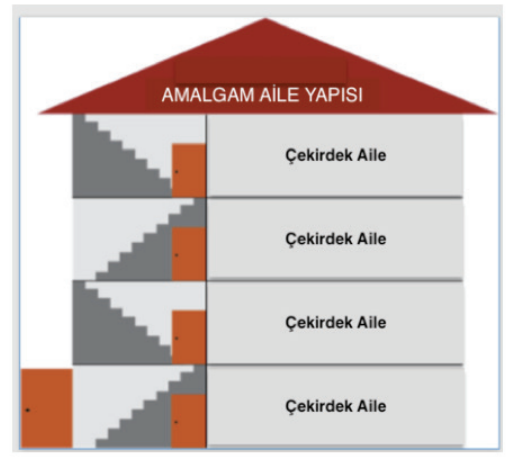

Şekil 2

Amalgam Aile Yapıs1 
'Zaman' sınırlı bir kaynak olarak çalışan anneler için çok değerlidir. Dünya Bakım ekonomisine göre ücretsiz bakım emeğinin \%75'ini kadınlar yüklenmektedir (EIGE, 2020). Ücretsiz bakım emeği, kadınların yüksek oranda (\%60.2) zaman yoksulluğu da yaşadığını göstermektedir. Zaman yoksulluğu oranı erkekler için \%9.6 olarak verilmektedir. Ev içi ücretsiz emek yükünün eşler arasında dengeli dağıll$\mathrm{m} ı$ çalışan kadınlara bakım hizmetleri sorumluğunu paylaşma ve sosyal etkinliklere daha fazla katılma fırsatları yaratmaktadır. Bu araştırmada babaların ücretsiz ev işleri emeği ve çocuk bakım sorumluluğunun ilişkili olduğu bulunmuştur. Ev içi ücretsiz emek yükünü paylaşan babalar aynı zamanda çocuk bakım sorumluluğunu da alan babalar olmuşlardır. Bu baba katılımlarının, geniş aileyle dolayısıyla bakıcı büyükannelerle de ilişkili olduğu gözlemlenmiştir. Dünyanın farklı ülkelerinde olduğu gibi, kadınların ev içi bakım işleri için harcadıkları ücretsiz emek konusunun Kuzey Kıbrıs'ta da sosyal politikalar düzenlemeleri içerisinde ciddiyetle ele alınması, toplumsal cinsiyet çalışmaları açısından önemli bir öğe olarak görülmektedir.

Hane gelirleri yüksek olan aileler, ev işleri ve bakım hizmetlerinin bir bölümü için piyasa hizmetlerinden yararlanma firsatına sahip olabiliyorlar (İlkkaracan, 2013; 2017). Örneğin, erken çocukluk dönemindeki çocukları ve bazı ev işleri için bakıcı ve/veya ev hizmetli ve çocukları kreşe gönderme gibi masrafları ödeyebiliyorlar. Bu araştırmada kadınların, iş gücü piyasasında kalmaya devam etmelerinde, geniş aileden ücretsiz hizmet olarak aldıkları, çocuk bakımı desteğinin, önemli bir öğe olduğu gözlemlenmiştir. Özellikle büyükannelerin sağladığı ücretsiz çocuk bakım hizmeti, sosyo-ekonomik sınıf farkı gözetmeksizin uygulanan bir yöntem olarak ortaya çıkmaktadır.

Çocuk bakımı ve eğitimi, ailelerin çocuğa verdiği değer ve yetiştirme stilleri (Kağıtçıbaş1, 2007; Kağıtçıbaş1 \& Ataca, 2005) sosyal ve bağlamsal olayların parçasıdır. Araştırmaya katılan annelerin çocuklarına karşı gösterdikleri eğitici ebeveyn tutumları, az da olsa baba katılımı, gün içi büyükanne bakımı, geniş ailenin çocuğun yetiştirilmesinde gereksinim duyulan diğer öğelere katkıda bulunması, Kuzey Kıbrıs'taki aileler için, sağlıklı ve mutlu çocuk yetiştirmenin, kültürel olarak önemli olduğunu göstermektedir. Ancak ailelerin kendi çabalarıyla kurmaya çalıştıkları erken çocukluk dönemi büyükanne bakım yöntemi, kadının geleneksel çocuk ve aile bakım sorumluluğunu pekiştirir niteliktedir. Kadına yüklenen çocuk yetiştirme rolü, büyükanne statüsünde de devam etmektedir (Shwalb, Hossain \& Eisberg, 2019)

$\mathrm{Bu}$ araştırmada belirgin bir şekilde ortaya çıkan öğe, yaşamın ilk yıllarında çocuk bakımının büyükannelere yüklenmiş olmasıdır. Bu zorunluluktan kaynaklanan durum, yetersiz kreş sayısı ve kreş ücretlerinin oldukça yüksek olmasıyla bağlantı11dır. Halen sosyal politikalarda etkin bir şekilde yerini almayan toplumsal cinsiyet eşitliği bakış açışı, ücretsiz ev bakım emeğini gündeme taşımadığı gibi, ülkedeki ücretsiz ve/veya ailelerin bütçelerine uygun kreş hizmetleri sunmayı da ertelemektedir. Çocuk yetiştirmek için koca bir köy gerekir! Bronfrenbrenner (1986)'nın önerdiği 
gibi sağlıklı kuşaklar yetiştirebilmek için, çocuktan başlayarak aile ve diğer sosyal (Örn. Kreş) çevrelerin katılımlarını, zaman boyutuyla dolayısıyla içinde bulunulan kültürle değerlendirmek gerekir.

Öncelikle bu çalışma kesitsel araştırma yönteminin tüm sınırlılıklarını içermektedir. Aynı zaman dilimi içerisinde katılımcılardan veri toplanmış ve katılımcılar arası karşılaştırmaya yoğunlaşılmıştır. Dolayısıyla, bu çalışmada neden-sonuç ilişkileri değil yalnızca ele alınan değişkenler arasındaki ilişkiler analiz edilmiştir.

$\mathrm{Bu}$ çalışmanın sınırlılıklarından biri de çalışmaya katılan annelerin çalışma statüsündeki dengesiz dağılımdır. Gelecekte yapılacak olan araştırmalarda büyükannelerle ilgili yaş, önceki çalışma statüsü gibi daha ayrıntılı bilgiler alınması kadına yüklenen çocuk yetiştirme rolü üzerinde daha ayrıntılı veri oluşturmasını sağlayabilecektir. Özellikle, büyükannelerin yaş ranjlarının (Örn. 45-50 veya 70-75) hem çocuklarla iletişimleri hem de sosyal politikalar açısından önemli ip uçları verebilecektir. Giderek yükseltilen emeklilik yaşı, sonraki kuşaklar için büyükannelerin torun bakımını üstlenmelerini mümkün kılmayacağına işarettir. Büyükannelerin yanı sıra büyükbabalarla (büyükbaba katılım/katkısı) ilgi verinin toplanması da (Örn. baba ve büyükbaba ücretsiz ev bakım emeği) farklı kıyaslamalar yapılmasına fırsat verebilecektir. Ayrıca son dönemlerde Kuzey Kıbrıs'ta yaşanan nüfus hareketliliği göz önünde tutulduğunda, göçmen kökenli ailelerle bu çalışmanın tekrarlanması, özellikle babaların babalık algılarının çalışılması (Birkalan-Gedik, 2014) literatüre büyük katkı sağlayacak nitelikte olacaktır. Bir başka değerli veri, kullanılan soru kâğıdının babalar tarafından doldurulması ile sağlanabilir. Böylelikle babanın eğitici ebeveyn tutumu, ücretsiz bakım emeği ve çocuk bakım sorumluğu, annenin gözüyle değil doğrudan babanın kendi ifadeleriyle elde edilecektir.

Yaşamın ilk yılı bakıcı büyükanne rolünün ve ailenin çocuk yetiştirme konusunda geniş aileden aldığ 1 destek Kuzey Kıbrıs örnekleminde nereye kadar devam edecektir? Yaşam boyu bakım (çocuk, engelli, yaşlı) ve ücretsiz bakım emeği dolayısıyla cinsiyete dayalı iş bölümü değiştirilebilecek mi? Bu sorulara çözüm kültürel kodlar ve sosyal ve kültürel tutumları çalışan araştırma sayısı ve feminist psikoloji, feminist ekonomi gibi farklı disiplinlerden feminist yayınların artırılması ile mümkün olabilecektir. Ancak bilimsel veri ışığında, toplumsal cinsiyet eşitliği bakış açısı sosyal politikalarda yerini alabilecektir. Böylelikle, hükümetler \%50 nüfusunu inkar ederek, istismar etmeyecektir.

\section{Kaynakça}

Arnett, J. J. (2008). The neglected 95\%: Why American psychology needs to become less American. American Psychologist, 63(7), 602-614. https://doi.org/10.1037/0003-066X.63.7.602

Atalay, M. \& İnan-Uzman, B. (1998). Kıbrıs Türkünün değişim ve gelişiminde Kıbrıs Türkkadın dernekleri, DAÜ-KAM, Gazimağusa, Kuzey Kıbrıs.

Balleyguier, G. (1979). Test pour l'evaluation du aractere de l'enfant et des attitudes educatives de 
l'entourage: $f c b$. Editions scientifiques et psychologiques, Paris, France.

Balleyguier, G. \& Melhuish, E. C. (1996). The relationship between infant day care and socioemotional development with French children aged 3-4 years. European Journal of Psychology of Education, 11(2), 193-199.

Balleyguier, G., Majunow, B., Godeau-Rébières, M. H. \& Mertan, B. (1994). Types d'attachement et étroitesse du lien mère-enfant: comparaison de trois milieux sociaux et culturels. İçinde, M. Deleau \& A. Weil-Barais (Editörler), Le développement de l'enfant, approches comparatives, 223-232.

Baumrind, D., Larzelere, R. E. \& Owens, E. B. (2010). Effects of preschool parents' power assertive patterns and practices on adolescent development. Parenting: Science and Practice, 10, 157-201.

Belsky, J. (1984). The determinants of parenting: A process model. Child Development, 83-96.

Belsky, J. (1988). The "effects" of infant day care reconsidered. Early Childhood Research Quarterly, 3(3), 235-272.

Belsky, J. \& Rovine, M. (1990). Patterns of marital change across the transition to parenthood: Pregnancy to three years postpartum. Journal of Marriage and the Family, 5-19.

Birkalan-Gedik, H. (2014). Politik bir alan alarak babalık: Almanya'da Türkiyeli babaların deneyimleri. İçinde, N. Boztekin (Editör), Başka bir aile anlayışı mümkün mü? 263-275.

Bornstein, M. H. (2012). Cultural approaches to parenting. Parenting, 12(2-3), 212-221.

Bornstein, M. H., \& Putnick, D. L. (2007). Chronological age, cognitions, and practices in European American mothers: A multivariate study of parenting. Developmental Psychology, 43(4), 850.

Bronfenbrenner, U. (1986). Ecology of the family as a context for human development: Research perspectives. Developmental Psychology, 22, 723-742.

Cabrera, N. J. \& Tamis-LeMonda, C. S. (2013). Handbook of father involvement: Multidisciplinary perspectives. Routledge.

Dedeçay, S. S. (1993). Lefkoşa özel Türk üniversitesi ve Kıbrıs’ta yüksek öğretim çabaları. Lefkoşa: Lefkoşa Özel Türk Üniversitesi. 10.

Goossens, F.A. \& Van Ijzendoorn, M.H.(1990). Quality of infants'attachments to professional caregivers: Relation to infant-parent attachment and day-care characteristics. Child Development, 61(3), 832837.

Hadjipavlou, M. \& Mertan, B. (2010). Cypriot feminism: An opportunity to challenge gender inequalities and promote women's rights and a different voice. The Cyprus Review. A Journal of Social, Economic and Political, Special Fall Issue 22(2), 247-268.

Hadjipavlou, M. \& Mertan, B. (2019). A multilevel intervention:The case of the Cyprus gender advisory team (GAT) Achievements and challenges. Journal of Peacebuilding \& Development, 1-13, DOI: $10.1177 / 1542316619843258$.

Henrich, J., Heine, S. J. \& Norenzayan, A. (2010). The weirdest people in the world? Behavioral and Brain Sciences, 33(2-3), 61-83.

İlkkaracan, İ. (2012/2013). Work-family balance and public policy: A cross-country Perspective, Development, 55(3), 325-332.

İlkkaracan, İ. (2017). Mor ekonomi sürdürülebilir kentler yolunda kadınların eşit ekonomik katılımı için bir strateji. İstanbul: Türkiye Ekonomik ve Sosyal Etüdler Vakfı (TESEV).

Kagan, J., Snidman, N. \& Arcus, D. (1998). Childhood derivatives of high and low reactivity in infancy. Child Development, 69(6), 1483-1493.

Kağıtçıbaşı, Ç. (2012). Kültür ve ana babalık. Kuram ve uygulama çıkarsamaları. Ana Babalık: Kuram ve Araştırma, der. Melike Sayll, Bilge Yağmurlu, 1, 61-79.

Kağıtçıbaşı Ç. (2007). Family, self, and human development across cultures: Theory and applications. Routledge.

Kağıtçıbaşı Ç. (2010). Türkiye'de kadın ve eğitim. Türkiye'de toplumsal cinsiyet çalışmaları. İstanbul: 
Koc, Üniversitesi, 9-19.

Kağıtçıbaşı Ç. \& Ataca, B. (2005). Value of children and family change: A three-decade portrait from Turkey. Applied Psychology, 54(3), 317-337.

Lamb, M. E. (1998). Nonparental child care: Context, quality, correlates and consequences.

Lamb, M. E. (2010). How do fathers affect children's development? Let me count the ways. içinde. (M. E. Lamb, Editör) The Role of the father in child development (5. Bask1) Hoboken, NJ: Wiley, 1-26.

Lamb, M. E. \& Tamis-Lemonda, C. S. (2004). The role of the father: An introduction. (M. E. Lamb, Edit.) The Role of the father in child development (4. Bask1), New York, NY: John Wiley \& Sons.

McMunn, A., Martin, P., Kelly, Y. \& Sacker, A. (2017). Fathers' involvement: Correlates and consequences for child socioemotional behavior in the United Kingdom. Journal of Family Issues, 38(8), 1109-1131.

Mertan, B. (1995). Gardes des jeunes enfants par la grand-mère à Chypre du Nord, Les Cahiers du CERFEE, Centre de Recherche Formation Enfance Education, Socialization et Construction Cognitive, 11-12, 289-290, University of Montpellier, France.

Mertan, B. (2000). Doğu Akdeniz Üniversitesi'nde kadının konumu: Bir inceleme. Woman 2000, Journal for Woman Studies, EMU-CWS, 1(1) 1-9.

Mertan, B. (2003). Social and emotional development of Turkish Cypriot children and caregiving styles. Woman 2000, Journal for Woman Studies, EMU-CWS, 3(2) 1-16.

Mertan, B. \& Boulanger-Balleyguier, G. (2008). Quelques conséquences du travail des mères sur leurs représentations des relations mère-enfant dans une société européenne en mutation. Revue Enfance, 60(4), 393- 406 Paris: PUF.

Orloff, A. S. (2009). Gendering the comparative analysis of welfare states: An unfinished agenda. Sociological Theory, 27(3), 317-343.

Öner, N. ve LeCompte, W. A. (1985). Durumluk-sürekli kaygı envanteri el kitabı. Boğaziçi Üniversitesi.

Ray, R., Gornick, J. C. \& Schmitt, J. (2010). Who cares? Assessing generosity and gender equality in parental leave policy designs in 21 countries. Journal of European Social Policy, 20(3), 196-216.

Rollè, L., Gullotta, G., Trombetta, T., Curti, L., Gerino, E., Brustia, P. \& Caldarera, A. M. (2019). Father involvement and cognitive development in early and middle childhood: a systematic review. Frontiers in Psychology, 10, 2405.

Rubin, K. H., Burgess, K. B. \& Hastings, P. D. (2002). Stability and social-behavioral consequences of toddlers' inhibited temperament and parenting behaviors. Child Development, 73(2), 483-495.

Schneider, B. (2014). Child psychopathology. From infancy to adolescence. Cambridge University Press.

Shwalb, D. W., Hossain, Z. \& Eisberg, G. (2019). The roles of grandparents in child development: a cultural approach. Children's Social Worlds in Cultural Context Cham: Springer,161-172.

Sicouri, G., Tully, L., Collins, D., Burn, M., Sargeant, K., Frick, P. \& Dadds, M. (2018). Toward father-friendly parenting interventions: A qualitative study. Australian and New Zealand Journal of Family Therapy, 39(2), 218-231.

Tanskanen, A. O. \& Danielsbacka, M. (2018). Multigenerational effects on children's cognitive and socioemotional outcomes: A within-child investigation. Child Development, 89(5), 1856-1870.

Tomlinson, M., Bornstein, M. H., Marlow, M. ve Swartz, L. (2014). Imbalances in the knowledge about infant mental health in rich and poor countries: Too little progress in bridging the gap. Infant Mental Health Journal, 35(6), 624-629.

Williams, S. K. \& Kelly, F. D. (2005). Relationships among involvement, attachment, and behavioral problems in adolescence: Examining father's influence. The Journal of Early Adolescence, 25(2), 168-196. 


\section{Elektronik kaynaklar}

Andersson, B. E. (2003). Childcare and Its Impact on children 0-2 years of age commenting: Belsky, Howes, and Owen. Encyclopaedia on Early Childhood Development, www. child-encyclopaedia. com.

CEDAW (1979). The Convention on the Elimination of All Forms of Discrimination against Women. Erişim tarihi 16 Şubat 2021, https://www.un.org/womenwatch/daw/cedaw/

CSW64 (2020). Beijing + 25: Realizing Gender Equality and the Empowerment of all Women and Girls. Commission on the Status of Women. Erişim tarihi 16 Şubat 2021,https://www.unwomen. org/en/csw/csw64-2020

CSW65 (2021). Women in Public Life Equal Participation in Decision-Making- End Violence- Achieve Gender Equality. Commission on the Status of Women. Erişim tarihi 16 Şubat 2021,https://www. unwomen.org/en/csw/csw65-2021

European Comission, (2015). Joint Employement Repot 2015. Erişim tarihi 16 Şubat 2021, https://data. consilium.europa.eu/doc/document/ST-7006-2015-INIT/en/pdf Eurostat (2019). Women in the EU are having their first child later. Erişim tarihi 16 Şubat 2021, https://ec.europa.eu/eurostat/en/web/ products-eurostat-news/-/ddn-20210224-1

EIGE (2020). Gender Equality Index 2020: Digitalisation and the Future of Work. Erişim tarihi 16 Şubat 2021, https://eige.europa.eu/publications/gender-equality-index-2020

The Istanbul Convention (2012). The Convention on Preventing and Combating Violence against Women and Domestic Violence. Erişim tarihi 16 Şubat 2021, https:/www.coe.int/en/web/ conventions/full-list/-/conventions/treaty/210 ()

KKTC İstatistik Kurumu (2019). İstatistik Y1llığı 2019. Erişim tarihi 16 Şubat 2021, http://www.stat. gov.ct.tr/IST-YIL-2019.aspx

KKTC İstatistik Kurumu (2019). 2020 Hanehalkı İşgücü anketi Sonuçları. Erişim tarihi 16 Şubat 2021, http://www.stat.gov.ct.tr/HIA-BULTEN-YIL-7.aspx

OECD (2019a). Gender Differences in Employment. OECD Family Database. Erişim tarihi 16 Şubat 2021, http://www.oecd.org/els/family/database.htm.htm

OECD (2019b). Health at a Glance 2019: OECD indicators. Erişim tarihi 16 Şubat 2021, https:// www.oecd-ilibrary.org/sites/fa1f7281en/index.html?itemId=/content/component/fa1f7281. SDGS (2015). UN Department of Economic and Social Affairs. Sustainable Development en/index. html?itemId=/content. Erişim tarihi 16 Şubat 2021, https://sdgs.un.org/goals/goal17

WHO/HRP (2015). Sezaryen Doğum Hızları ile ilgili DSÖ Açıklaması. Department of Reproductive Health and Research World Health Organization. Erişim tarihi, 16 Mart 2021, https://apps.who.int/iris/ bitstream/handle/10665/161442/WHO_RHR_15.02_tur.pdf;jsessionid=F3EADF5B744E03C62BBFB 9381AC2710A?sequence $=11$

World Bank (2020): “World Development Indicators,",Erişim Tarihi, 16 Mart 2021, http://data. worldbank.org/data-catalog/world-development-indicators adresinden erişildi.

World Economic Forum (2020). Global Gender Gap Report 2020. Erişim tarihi 16 Şubat 2021, tarihinde https://www.weforum.org/reports/global-gender-gap-report-2020 